\title{
Trusted Markets: The Exchanges of Islamic Companies
}

\author{
GÜL BERNA ÖZCAN ${ }^{1} \&$ MURAT ÇOKGEZEN ${ }^{2}$ \\ ${ }^{1}$ School of Management, Royal Holloway, University of London, Egham, Surrey, \\ TW0 0EX, UK. E-mail: G.0zcan@rhul.ac.uk \\ ${ }^{2}$ Department of Economics, Marmara University, 34590 Bahcelievler, Istanbul, \\ Turkey
}

In recent years, Turkey has witnessed a new form of corporate finance in which companies, commonly called 'Islamic', borrow directly from lenders without using any financial intermediaries. Trust among lenders and borrowers has initiated market exchange, secured deals and lowered transaction costs. This paper claims that the base of trust in direct financing for Islamic companies should be largely attributed to the self-interest of the parties rather than just to Islam or 'shared values'. Here we do not see an individual calculation of 'economic man', as argued by neo-classical economists, but individuals embedded in relations within social groups and sharing ethics of money-based relations. Second, we illustrate that selfinterest based trust stems from the calculations of trusters using available information in the market about trustees. However, information asymmetry between borrowers and lenders in favour of borrowers has been a source of deep instability and abuse. Finally, the paper shows how groups have used the rhetoric of Islamic economic revival to expand the scope of transactions while trust eroded in favour of abusers. The anonymity came with thousands of investors who eroded the strength of reciprocity, surveillance and retribution in trust-based relations. This case study also illustrates that Islamic societies seek new solutions within capitalist economic systems to maximise their gains and they do not wish to be destined to live in poverty.

Comparative Economic Studies (2006) 48, 132-155. doi:10.1057/palgrave.ces.8100073

Keywords: trust, Islamic companies, transactions costs, information asymmetries

JEL Classifications: A10, A14, O10, O14, G14, P14, P52, Z12 


\section{INTRODUCTION}

In recent years, Turkey has witnessed a new form of corporate finance in which companies, commonly called 'Islamic', borrow directly from lenders without using any financial intermediaries. The title 'Islamic' refers not only to the firms but also to the financial system and the business ethics within which both borrowers and lenders are bound together by a shared interpretation of Islam in economic principles. The main source of capital has come from local residents of conservative, small- and medium-sized Anatolian cities and Turkish workers abroad who invested their savings to purchase 'share-bonds' issued by the companies. The core principle of this form of borrowing rested upon the refrain from usury, which is considered prohibited for Muslims. ${ }^{1}$ Although this Islamic character of the system and its informal business nature has constantly being scrutinised by Turkey's secular political regime, Islamic companies never suffered from lack of interest by small investors.

Financial institutions replace direct transactions in the market because of their advantages in reducing transaction costs. Islamic companies instead use direct borrowing and bypass financial institutions. They mainly aim to eliminate usury in their business dealings and to create their own capital outside financial institutions by facilitating informal channels and eliminating costs associated with borrowing. Revealingly, despite the availability of Islamic banks in the market, these companies chose not to use any financial intermediary institutions. However, such direct and informal financing has many risks associated with it. Potential transaction costs in this system are very high for lenders, for many reasons. First, there is a huge information gap between borrowers and lenders, which is filled with informal assurances and/ or with misinformation. Second, the channels of monitoring and intervening in managerial activities or in leaving the system are severely restricted. Third, there is no legal way to enforce contracts if the borrower does not comply with the payment of dividends or the lender seeks speculative interest. Considering all these disadvantages, how can we explain the existence of Islamic companies in the context of transaction costs and financial institutions? For that we turn to the concept of 'trust'. Trust among lenders and borrowers has initiated market exchange, secured deals and lowered transaction costs.

${ }^{1}$ What the Koran clearly prohibits is Riba, a pre-Islamic practice of doubling the debt of a borrower who is unable to repay his loan. The definition and content of usury, and the applicability of verses on Riba to the term 'interest' are problematic issues among Islamic scholars (Kuran, 1995). For the purpose of this paper, we use the term 'usury' for any kind of interest banned by Islam. 
Trust is regarded as a 'lubricant' of social systems (Arrow, 1974). Indeed, it facilitates transactions and raises the efficiency of a system when the market fails. In this paper, we argue that trust plays the role of the invisible hand in facilitating market exchange, reducing uncertainties and asymmetric information problems where financial institutions and regulatory regimes are underdeveloped or ineffectual. As our analysis of Islamic companies illustrates, trusted parties reduce the risks and uncertainties stemming from information asymmetries in imperfect markets and create alternative financial capital for businesses outside financial institutions. Thus, by reducing transaction costs, trust minimises the costs associated with borrowing for the firms and costs of writing and surveillance of contracts for both parties (borrowers and lenders) in their market exchange. But, our analysis also shows how the construction of trust based on Islamic morality cannot prevent abuses. On the contrary, while repeated transactions enhance and bind the trust of lenders, the asymmetric information problems and anonymity augment the temptation of borrowers to engage in abusive behaviour.

The role of trust in the emergence, existence and persistence of Islamic companies is always linked with the virtues of justice, honesty and altruism that are believed to be ideally possessed by all Muslims. Many people believed that Muslims who invested in Islamic companies had thought that, by virtue of their faith, entrepreneurs of Islamic companies would not abuse the one-sided advantages the 'share-bonds' provided for them. However, in this context, we do not see virtuous characteristics attributed to Muslims as the only source of trust. On the contrary, investors' decision to trust any given entrepreneur is based on their calculations comparing possible benefits and costs of engaging in contracts. Similarly, entrepreneurs choose to fulfil or renege on their commitments because it is in their best interests to do so.

We claim that the base of trust in the system should be largely attributed to the self-interest of the parties rather than just to Islam or shared values. Here we not only see an individual calculation of 'economic man', as argued by neo-classical economists, but also individuals embedded in relations within social groups and sharing morals of money-based relations. This point has rarely attracted interest from economists. ${ }^{2}$ We also illustrate that selfinterest-based trust stems from the calculations of trusters using available information in the market about trustees. However, information asymmetry between borrowers and lenders in favour of borrowers has been a source of

\footnotetext{
${ }^{2}$ The edited volume of Ben-Ner and Putterman (1998) is one of the rare examples of such a work, devoted to the relationship between values and economics.
} 
deep instability and abuse. ${ }^{3}$ Finally, the paper shows how groups have used the rhetoric of Islamic economic revival to expand the scope of transactions while trust eroded in favour of abusers. The anonymity came with thousands of investors who eroded the strength of reciprocity, surveillance and retribution in trust-based relations. Moreover, the lack of institutional and regulatory regimes is making this moral collapse even more painful for the remaining investors, managers and local economies.

Islam provided the necessary ethical and moral ground for wealth creation with a market friendly interpretation. This aspiration should also be seen within the context of the ambitions and unfulfilled expectations of Muslims living in capitalist societies. ${ }^{4}$ In particular, Turkish workers in Germany who constituted the majority of lenders invested their family savings while seeking an ideal future and 'just order' for themselves and their children. The repeated exchange of trust among individuals and groups forged with the rhetoric of Islamic economic revival expanded the scope of transactions. We illustrate, however, how maintaining trust through market exchange and reputation becomes difficult when these companies become mainstream players with many imitators.

Adherence to a moral code in a small group brings high costs for noncompliance since deviant behaviours are recorded and punished (Ben-Ner and Putterman, 1998). In the beginning, therefore, it was in the interest of borrowers and lenders to remain honest and adhere to the moral codes of Islam. But, with the increasing number of investors, geographical distance and diverse business investments, remembered acts and reciprocal arrangements lost their strength. While the consequent anonymity led to increased chances of unmonitored abuses, the moral and economic overload of Islamic institutions failed to discipline parties. As the moral integrity of the regime weakened, it exposed the companies to managerial abuses and the uncertainties of the market.

This paper contributes to the academic literature in several areas such as the relationship between trust and morality; the role of trust in transaction costs economics (Noorderhaven, 1996); building trust and manipulating trust in socio-economic relations (Dasgupta, 2000; Ensminger, 1997; Grief, 1994; Nelson, 1974); trust as a substitution to assymetric information problems

\footnotetext{
${ }^{3}$ The source of instability stemming from asymmetric information problems is well illustrated by Mishkin (1992).

${ }^{4}$ For an interesting discussion of the contradictions of modern Muslims, see Shayegan (1992) and Kuran $(1989,1995,1997)$. The source of modern discontent is not only an issue for the Muslims but a general concern linked to increased inequality and globalisation. Nevertheless, poverty, the radicalisation of religion, and the economic backwardness of the Islamic world raises deep existential and moral dilemmas for modern Muslims.
} 
(Greenwald and Stiglitz, 1990; Mishkin, 1992); and, last but not least, the role of morality and religion in economic lives of modern Muslims and the future of Islamic economics (Kuran, 1989, 1995, 2003).

The paper is divided into five parts. In the following section, we analyse financial institutions and imperfect markets. Then we provide a background analysis of Islamic companies in Turkey. In the third section, we introduce calculative trust and market exchange followed by an illustrative analysis of trust and its manipulation. Our conclusion highlights the limits of trust as a moral code as well as an invisible hand in facilitating transactions and direct financing.

\section{FINANCIAL INSTITUTIONS AND IMPERFECT MARKETS}

In an ideal perfectly competitive market where information problems are absent, there is no need for financial institutions at all. Any individual or agent who needs finance for a project can find it without enduring any search costs. Lenders, on the other hand, can perfectly evaluate the project they are financing, make complete contracts, and enforce borrowers to obey the terms of the contract at no cost. In the imperfect markets of everyday life, all of these activities are costly. First, both lenders and borrowers have to endure search costs to obtain information about, meet, select and negotiate with the other parties of the contract. Securing and monitoring contracts and any possible violations are also costly. After the parties agree on the terms of the contract, lenders need to monitor the borrower to ensure the terms of the contract. Here we consider only the informational asymmetry between borrowers and lenders, which is a crucial impediment to an efficiently functioning financial system.

In financial markets, usually the supplier of a financial instrument issued to finance a project, in other words the borrower, has better information about potential risks and returns of the project than the lender. Therefore, the market price of any financial instrument reflects buyers' perceptions of the average quality of projects in the market. Such a pricing strategy drives good (above average) investment opportunities with low risk out of the market while promoting the entrance of riskier (below average) projects. In turn, it is more likely that the borrowers will make wrong decisions and finance riskier projects than they expected. This is called adverse selection. The risk of adverse selection causes a reduction of the market price lenders are ready to pay for financial instruments in conjunction with reductions in their perceptions about the average quality of projects. It also increases the number of riskier projects in the market. Following Akerlof (1970), one may 
conclude that this blurred environment in the extreme would wipe out all financial transactions.

The second problem associated with information asymmetry occurs after borrowers and lenders enter into a transaction. Borrowers may engage in activities that are undesirable from the lenders' point of view since they know that the lender is unable to observe and assess the actions he undertakes (this leads to moral hazard). A borrower conscious of informational advantages may invest in riskier projects since the risk is borne by the lender, but the borrower also benefits from the gains at the expense of the lender by allocating some of the resources for personal use. The moral hazard problem in the long run discourages lenders investing in financial instruments and reduces the volume of financial transactions in the market.

To sum up, informational asymmetry is one of the major causes of financial crises (Mishkin, 1992). The factors that worsen asymmetry such as increases in interest rates, bank panics, increases in political uncertainty, etc, cause lenders to withdraw their funds from the market and lead to a decline in investment and aggregate economic activity.

Like any other intermediaries in a market, financial institutions reduce transaction costs by exploiting the economics of scale and scope. Financial institutions have a comparative advantage in gathering information about borrowers over the individual efforts of lenders (Leland and Pyle, 1977). The provision of cheaper and more appropriate information reduces the risk of adverse selection. After the parties are agreed on the terms, monitoring and enforcement of most any contract is performed better if these activities are delegated to financial institutions rather than carried out by individual agents as they reduce the moral hazard risk (Diamond, 1984).

Considering theories that attribute the existence of financial institutions to the comparative transaction cost advantages of the options, the genesis of an alternative to financial intermediation can be explained by specific transaction cost advantages of alternatives from the lenders' point of view. Some lenders may believe that individually they can cope with informational asymmetries more efficiently. From the borrowers' side, the rationale for bypassing financial intermediaries is best explained by Leland and Pyle (1977). They claim that the borrowers who seek finance for projects with favourable risks wish to be identified. Therefore, they would deal with betterinformed financial intermediaries offering the exact value of their risks rather than with inadequately informed lenders offering the value of the average risk. Only borrowers with high-risk projects prefer to deal with uninformed lenders because they hope to reduce their risks.

The foregoing logic explains how Islamic companies emerged under the leadership of merchant entrepreneurs who employed their personal charisma 
and associated investment projects with their name and fame. These merchants travelled in Turkey and Germany to persuade potential investors and delivered sermons of Islam and 'just order' to convince often uninformed lenders to their risky investments as illustrated in the following section.

\section{ISLAMIC COMPANIES IN TURKEY}

Turkey has a bank-centred corporate finance system where the major source of external capital for companies has traditionally come from bank loans. In addition to routine activities such as borrowing and lending, banks in Turkey are intermediatries for almost all of the financial instruments in the market (Sak, 1995). However, the majority of banks are owned either by the state or leading family holding companies. Hence, large companies finance themselves via their own banks by using their ownership links or a state-owned bank susceptible to political influence. The bank-centred form of business finance in Turkey has been functioning through cozy relations between major business groups, industrialists and politicians (see Buğra (1994) for Turkey and Maxfield and Schneider (1997) for other similar economies). Credit rationing by big business and massive government borrowing reduce the survival chances of new entrants. They also limit the growth potential of small- and medium-sized companies (Özcan, 1995).

Another feature of Turkey's financial regime is the small market capitalisation and the periodic abuse of small investors by holding companies and the state. As explained by Özcan and Çokgezen (2003), the Turkish experience with capital markets has been driven by the short-term political and financial objectives of governments, mainly to fund populist policies. These characteristics severely damaged the creation of credible capital markets, channelled family savings to unproductive and unregistered economic activities, and have led to the persistent abuse of small investors. Since the 1960s Turkish workers' remittances from western Europe (mainly from Germany) provided a regular flow of foreign currency, which until the 1980s constituted the major source used to balance the trade deficit of the country. Many workers had difficulty investing their savings in productive investments rather than purchasing real estate and gold. Thus, Islamic companies emerged as an alternative investment for families with small savings who were trying to accommodate the constraints of weak financial market regulation, periodic abuses and limited investment opportunities in an inflationary economy. ${ }^{5}$

\footnotetext{
${ }^{5}$ Turkey has long suffered endemic high inflation rates ranging between $60 \%$ and $70 \%$ throughout the last decade. Thus, the recent drop to $10 \%$ is considered a remarkable success.
} 
Prototypes of Islamic companies first occurred in the 1980s and the model became popular in the 1990s. ${ }^{6}$ During this period, the Turkish economy experienced a transformation towards a more liberal economic system with wider opportunities for entrepreneurial activities. The new economic policy embarked upon in 1980 had deep and contrasting impacts on different segments of the society. On the one hand, it created new opportunities for those who could adapt themselves to the rules of an opening economy. On the other hand, many who could not take advantage of liberal market opportunities, such as small producers, the lower middle classes and labourers, felt marginalised. Income gaps between social groups have widened over the years (Özcan and Özcan, 2003). This new economic order went hand in hand with the increased media exposure of the wealthy and their consumption of luxury goods. The media also introduced and promoted decadent values foreign to ordinary Muslims. ${ }^{7}$ Islamic politics embraced losers and the alienated masses of the liberal regime with the promise of a 'just order'. Political Islam focused its campaign on protecting marginalised groups of poorly paid workers, shanty town dwellers and small capitalists from the 'aggression' of Western capitalism and culture. Hence, Islam not only brought legitimacy for political ideology but it was also used to foster solidarity among different segments of the society. Muslim Turks' concerns about discrimination and assimilation in Germany as well as their desire for a better future also made them susceptible to Islamic 'just order' propaganda.

Within party politics the synthesis between industrialisation, development and Islam took decades to find a receptive audience beyond its core engineers and thinkers. ${ }^{8}$ This branding of moral salvation with material

\footnotetext{
${ }^{6}$ The degree of diversity among the Islamic sects and fraternity organisations shows that this notion of common Islamic principles and moral beliefs do not form a unique and homogeneous entity or any ecclesiastical hierarchy and geography. Indeed, the Islamic business groups reflect this difference of interpretation under the influence of different philosophies and religious leaders (see Çakır, 1995).

${ }^{7}$ Without being too puritanical about this, what we refer to includes extensive broadcasting of soft pornography, voyeuristic 'reality TV', and crass game shows and talk shows, as well as their print counterparts. Mainstream Turkish newspapers and TV channels seem to rely on scandals, celebrity gossip, and shocking stories of mafia violence, sex and drugs. One recent case, the death of a former beauty queen, Burçin Bircan, at the age of 21 years from an overdose of drugs revealed the sad account in her diary of the confusion and decadent behaviour of her peers.

${ }^{8}$ Çakir (1995) gives an elaborate account of Islamic groups and their intensified political and economic presence in Turkey during the 1980s and early 1990s. A notable organisation, the Iskender Paşa School, has led a significant intellectual debate on Islam and industrialisation through its thinkers and associated young graduates since the 1950s. Interestingly, among these graduates there have been high ranking civil servants and politicians who occupied influential positions in government institutions and politics.
} 
benefits points out the core sentiment which made the so-called 'Islamic economic order' attractive to ordinary investors. While the Islamic rhetoric condemned the individualistic societies of the West for being immoral, individual interests, nevertheless, occupied the core motivation for investing in Islamic holding companies. This paradox is addressed by Açıel (1996) as the desire of the repressed and marginalised masses to seek power. In agreement, Tugal (2002) identifies Islamic populism with unfulfilled aspirations and desires to change the hegemony. Çakır (1995) and Göle (1999), among others, see the rise of Islam as a movement against, and in response to, modernity. The Islamist party of the early 1990s, the Welfare Party, used the shortcomings of secularism as part of its propaganda to show its unique position in defending Islam and traditionalism as well as in bringing about a just society. Paradoxically, both strict secularism and political Islam have long survived side by side despite periodic clashes in Turkey. Indeed, as Shankland (1999) illustrates, Islam and Islamic politics were actually accommodated within the secular state establishment. Açıkel (1996) goes further to suggest that the Turkish-Islamic synthesis has been the semi-official ideology of the Republic from the 1950s onward. However, the Islamic movement and its discourse of 'just order' emerged from the margins of politics and from opportunities offered by the post-1980 economic liberalisation in Turkey and, as this research illustrates, it often took advantage of the liberal economic regime.

With the backing of the Welfare Party, later replaced by the Virtue Party (itself closed in 1998 giving way to the AKP under a new and more moderate leadership), and its cultural and business associations, Islamic companies were set up largely in socially conservative Anatolian towns where religious and community values have been strong. Konya, with its lively Islamic politics and numerous small businesses, has become the centre of activity. In Europe, Turkish workers, mainly in Germany, were organised in various Islamic associations, coffee-houses and mosques by representatives of the companies, aided by youth organisations of Islamic groups and their small town relatives and associates in Turkey. ${ }^{9}$ Talks and prayers were employed to persuade workers to invest their family savings in a new approach to industrialisation with moral justice.

\footnotetext{
${ }^{9}$ Islamic brotherhoods like Fetullahcis, Nakşibendis, and Süleymancis had their own business and finance groups both in Turkey and Germany. According to the study of the Turkey Research Centre, Asya Finance supported many businesses that favoured the moderate Fetullah Gülen group known as Fetullahci while İhlas Finance had ties with the Nakşibendi order and supported businesses associated with this group (Special Report on Islamic Finance and Businesses, 1999).
} 
The rhetoric of political Islam found popular support in Turkey and among Turkish workers abroad for different reasons. In Turkey, Islam was primarily seen as an alternative to unfettered capitalism, which was associated with increasing inequality, unfair competition for small firms, and increased moral and economic insecurity by the masses (Açıkel, 1999; Çokgezen, 2000). In Europe, it became more of an identity issue for Turkish workers. The Islamic companies were satisfying the emotional expectations and material interests of these groups for different reasons. The economic rationale of the investors also aligned with these psychological positions.

For years, investors saw their savings evaporate largely in low-return or speculative assets in Turkey. Ordinary investors shied away from stock market dealings and often preferred foreign currency or real-estate investments. Studies on household savings and investments quantify this trend and show that on average families retain their wealth in the form of real-estate (85\%) and bank accounts (11\%), while securities account for only $2.3 \%$ (Eser, 1999). Islamic companies were offering a 'fair' and high return (higher returns than German and Turkish banks pay for saving accounts) to those who buy the 'shares' of Islamic companies. At the same time, they believed they were acting to build a better future for their home country.

A study of 11 holding companies shows that over 80,000 shareholders purchased these company bonds. Among them the two largest ones, Yimpaş and Kombassan, have international investments and employ thousands of workers (Özcan and Çokgezen, 2003). Yimpaş, established in 1982 in the small Anatolian town Yozgat, currently has over 24 companies employing 10,000 workers, with investments in Germany, Bulgaria and Turkmenistan. Its main activities include hypermarket and supermarket retailing, food processing, entertainment and health services. Kombassan, established in Konya in 1989, employs 8,000 workers in its 40 companies that are also active in Khazakstan and Germany. Its main activities include paper products, packing materials, marble, textiles and shopping malls.

However, Islamic companies have major drawbacks from the standpoint of investors' property rights. First, even though the assets are called 'shares', unlike issued shares, investors are promised a certain amount of return beforehand, like bonds, and they have never earned negative returns. They are called 'shares' to circumvent the issue of interest, which most believe is prohibited in Islam. The shares are issued in the name of the holding company, an umbrella body financing other companies in the group, as a way of justifying permanent payments made by the companies. This is because the holding company is seen as a pool of the assets of different companies in the group. 
Second, the assets carry no property right defined legally. Shares in mainstream corporations usually give a vote to the holder to participate in managerial decisions. If individual shareholders cannot influence or change management, they can sell their asset as a reaction. However, 'shareholders' of Islamic companies have no legal rights to influence management if they are not satisfied. They also have very poor liquidity since there are no markets or intermediary institutions available to sell these 'shares'.

Third, the right to sell a 'share' is also restricted by the companies. 'Shareholders' who want to sell an asset before it is due have to apply to the company and to sell the 'share' to the person recommended by the company or wait until the term of the 'share' expires. More importantly, if the company fails to pay a 'dividend', they have no legal right to force the company to fulfil its commitments. Islamic companies persistently avoided their legal obligation to register with the Capital Markets Board (SPK) and ignored the rules for issuing bonds and shares. ${ }^{10}$ The SPK warned investors through public announcements about the illegality of these 'shares', but to no avail. Most of the practices to collect and transfer savings have been through informal channels. Another major drawback of the system is related to informational problems and there was never any regular means to obtain information to allow for shareholder participation. Informal information transmission channels like videos prepared by the companies and company visits were the major sources of information for investors.

These weaknesses have not prevented Islamic companies from becoming major attractions for investors and around 200 holdings were believed to be set up with the purpose of collecting assets from individual investors; not all but most using the rhetoric of Islamic politics and symbols of Islam (Odabaşı, 2001). Manufacturing was emphasised as the backbone of Islamic development in response to the underdevelopment of inner Anatolian regions. Thus, heavy industry and high-tech investments have been portrayed as priority investments by Islamic companies. But many companies failed to expand on early initiatives and often ended up in traditional manufacturing of consumer goods and services. However, not all of these initiatives have proven to be genuine. Indeed, the majority only existed in the window signs of empty offices, incomplete building sites, or just on paper or websites. Recent events revealed that some such companies, most notoriously Jet-Pa and Endüstri Holding, managed to funnel thousands of investors' savings to their principals and never made substantial investments. Some others did not

${ }^{10}$ The SPK Article 4 requires all issued papers to be regisreted with the Board and Article 47 requires transparancy and full information about issued papers and shares. All Islamic companies persistently disobeyed Artciles 4 and 47 of the SPK. 
fulfil their promises to the investors and new financial scandals have recently been unravelled by a court case in Germany. The Turkish daily Star (29.01.2004), quoting from the German magazine Der Spiegel, brought out serious financial abuse allegations against many Islamic holding companies, including the apparently successful ones like Yimpaş and Kombassan in addition to the fraudulent Jet-Pa.

\section{CALCULATIVE TRUST AND MARKET EXCHANGE}

Trust and asymmetric information are interconnected issues in market exchange. When parties trust each other, they engage in contracts without adequate safeguards (Noorderhaven, 1996) and save on the costs of transacting despite the existence of informational asymmetries. However, building trust is also subject to asymmetric information since trustees know better about themselves than trusters. Moral hazard and adverse selection problems arising from information asymmetries may, in turn, cause limited trust or none at all in the market and risk trust-based transactions.

The logic of building trust is a problematic issue in social sciences. Some scholars (Williamson, 1996; Dasgupta, 2000; Coleman, 1990) stress the importance of personal interests in building trust. From this perspective, trustees fulfil their commitments if it is in their interest to do so while trusters engage in contracts with inadequate safeguards if they decide that it is more likely that trustees will fulfil their commitments. They reach this conclusion on the basis of calculations based on relevant formal and informal information in the market. Some other studies (Granovetter, 1985; Lyons and Mehta, 1997a; Lane and Bachman, 1996) stress the importance of social factors and claim that parties also fulfil their commitments or engage in contracts in the name of some values, like belonging to a community, friendship, religion, etc, even if it is against their interests.

The formation of trust in Islamic companies may be viewed as a moral base of economic decisions through calculative rationing. Both Islamic ideologists and ordinary people usually believe that behaviours of good Muslims emanate from altruistic Islamic norms, which command honesty, fairness and caring about others, rather than the self-interest-based behaviours of the others. However, we believe that this is a highly exaggerated view for two reasons. First, studies on trust show that trust based on self-interest is more common in business relations and even moral reasoning has self-interest motivations (Williamson, 1996; Lyons and Mehta, 1997a). Second, in practice, the ideal Muslim society envisioned in Islamic texts has never been achieved in practice. There is no evidence that Muslims 
living in any part of the world have more virtuous behavioural patterns than others (Kuran, 1995).

We start our analysis from the entrepreneurs' (trustees) perspective. First, we should distinguish two kinds of entrepreneurs: "honest" and "dishonest". The latter gained the investors' confidence very easily thanks to externalities of trust. They entered into business after major companies, like Yimpaş and Kombassan, had benefited from the reputation created by initiators.

The other group, true entrepreneurs, were always sensitive about their payments and tried to remain on time, not because of their honesty but because they recognised that it was in their interest to do so. The ownership structure of the banking system and high interest rates in Turkey made direct borrowing more advantageous for companies that were able to do so. The persistence of direct financing was highly correlated with regular payments. It was very well known that any failure in payments would damage the reputation of the system as a whole and that the companies would have been deprived of easy financial resources.

On the investors' side the question is more problematic. The central question that should be answered is with regard to how 'shareholders' invested their money in these companies despite the fact that they had already known that they had no legal claims on the 'shares' they bought. This attitude can be attributed to the combination of several facts. First, those who believe a radical interpretation of Islam, who have a high propensity to save, avoid usury but live in a capitalist economy, do not have too many alternatives in which to invest their savings. They would either trust Islamic companies or stand by as their savings melt away. Second, the returns on shares are also higher than direct alternatives. Therefore, not only radical believers but also mainstream Muslims and even some non-Muslims invest in the system.

If two parties make a contract to exchange products that are specific to each other it is more likely that both parties will fulfil their commitments (Coleman, 1990). In the case of Islamic companies, both the borrowers' and lenders' hands are tied. Borrowers (including true entrepreneurs) have no other way than to go to specific groups for direct borrowing because of the contingencies, mentioned above, in the financial markets in Turkey. However, lenders who are restricted by Islamic rules have no other choice but to lend to Islamic companies to protect their savings against high inflation. To sum up, it is in both parties' interest not to cheat and to sustain the relationship. ${ }^{11}$

\footnotetext{
${ }^{11}$ This situation is similar to that described in Williamson (1987).
} 
The interdependence argument may explain why true entrepreneurs did not breach their contract. But, that leaves to the lenders the problem of distinguishing true entrepreneurs from swindlers. The problem of whom to trust was commonly solved by evaluations of individual lenders and their communal ties. Investors collected and evaluated all information available in the market. All the information available for calculation may be inconvenient, ambiguous or manipulated. But as shown by Tversky and Kahneman, people rely on a limited number of heuristic principles, which reduce the complex task of assessing probabilities and predicting values to a simpler judgemental operation. These heuristics sometimes lead to severe and systematic errors. This does not mean that they do not make calculations but only that they may make miscalculations. The next section is about these heuristics. We will show what kind of information the lenders used to make their judgements about the borrowers.

\section{TRUST: SELF-EXISTENT, CONSTRUCTED AND MANIPULATED}

In economic theory, an individual is endowed with preferences regarding her own consumption. But as Ben-Ner and Putterman (1998) rightly argue, individuals also have preferences with respect to others (other-regarding preferences). In the everyday life of Islamic societies where there is still strong manifestation of communal and tribal ties, other-regarding preferences as well as conformity-regarding preferences are also important in defining individuals' choices.

Thus, individual investors were motivated by self-interest and they made a choice following their moral judgement, which was intricately linked to a community view. The different layers of trust were constructed and manipulated through the language of Islam. Investing in an Islamic cause was also a search for redemption for guilt-ridden Muslims. ${ }^{12}$ Trust is first and foremost constructed through family, kin and communal lines under the moral guardianship of Islamic belief. The Islamic companies identified, primarily, family savings of Turkish workers abroad and, secondly, small town businessmen and families in Turkey as their main sources of capital. From the modest beginnings of a small number of investors, early entrants like Kombassan and Yimpaş quickly benefited from a rapid increase of investors following the reputation built on the high returns to early investors.

\footnotetext{
${ }^{12}$ As Kuran (1998) points out, the everyday life moral dilemmas of individuals highlight the clashes between values rooted in the conditions of small communities and the experiences of surviving in a dynamic modern economy for ordinary Muslims.
} 
As many potential investors identified this as a good sign of the trustworthiness of the company financial regime, the number of investors drastically increased into thousands. ${ }^{13}$

\section{Informal networks and conformity}

The importance of personal relations, based on family ties, friendship and business relations in building trust, is stated frequently in studies of trust. These ties underlay behavioural norms of mutual compliance and cooperation, which go along with solidarity and conformity, which in turn reduces uncertainties. Such desire is particularly high in societies going through rapid social and economic changes with the limited political stability, institutional safeguards, and welfare provisions found in Turkey. Similarly, the speed of urbanisation, the disintegration of traditional values and political as well as economic instability increase the need and desire to be in secure environments protected from the volatile consequences of economic and political change. Such comfort is first sought within the family and then in a more extended form through kin, friends and sub-communities in neighbourhoods. Anthropological studies recognise the depth of family and kin relations in economic and monetary relations of Turkish society (see White, 1994; Özcan, 1995).

White (1994) demonstrates how family and kinship ties are enhanced by money relations in Turkish society. Her anthropological work supports the findings of Parry and Bloch (1989) by indicating the intricate relations between monetary and social relations. ${ }^{14}$ She shows that a moral economy can exist under capitalist conditions and monetary relations are moulded within bonds of kinship and friendship. In the case of Islamic companies, trust built upon family and kin relations is secured through the financial commitments of investors in the early stages when the first investors were family members, kin and friends. This character of trust-based relations among family and kin accelerated a chain reaction with ever-increasing investors.

${ }^{13}$ According to a recent article in Der Spiegel (26.01.2004), more than 200,000 Muslims who lived in Germany have deposited billions in dubious Islamic firms. The report claims: 'that money has just disappeared'.

${ }^{14}$ According to Parry and Bloch (1989), the meaning of monetary transactions in pre-capitalist societies is 'the relationship between a cycle of short-term exchange which is the legitimate domain of individual-often acquisitive-activity, and a cycle of long-term exchanges concerned with the reproduction of social and cosmic order' (p. 2). However, the findings of White (1994) and our study illustrate that a moral economy and an internal social code can be interwoven within market exchange practices and transactions in capitalist relations, too. 
The influence of parental figures in family, kin and friendship ties have been strong in Turkish society, and Islamic preachers and communal leaders enjoyed this recognition. The spread of Islamic companies and their promised moral economic revival took root in social institutions often under the guiding leadership of a paternal figure who had indisputable authority and recognition. The desire to be protected by a father figure manifests itself in different forms such as the respect shown to religious and spiritual leaders, teachers or those with political charisma. ${ }^{15}$

\section{Islamic missionary and entrepreneur preachers}

Community leaders, religious teachers and preachers played a significant role in converting individuals to the idea of Islamic economic rejuvenation. The most successful Islamic companies have certainly benefited from this notion as they were set up and managed by charismatic leaders, businessmen and teachers who preached narratives of Islamic 'just order' constructed around honesty, intelligence and moral superiority. The chairman of Kombassan Holding, Haşim Bayram, is a good example of this teacher/ preacher with charisma. ${ }^{16}$ Like Kombassan, Yimpaş Holding was also established by a group of teachers who had worked together and enjoyed local recognition. ${ }^{17}$

The Islamic missionary zeal targeting Turkish workers in Germany and using a discourse of alienation, repression and fear of the 'other culture' managed to convert individuals to invest in Islamic companies. The number

\footnotetext{
${ }^{15}$ Süleyman Demirel, a former president and many time prime minister, now a retired veteran politician, was commonly referred as 'Father-Baba'. The ultimate example of this is the cult of Atatürk whose gazing portraits are displayed not only in official buildings but also in shops and houses voluntarily.

${ }^{16}$ Haşim Bayram was a very clever chemistry teacher who grew up in a poor rural area of the Konya Province and always imagined revolutionary industrial growth in the middle of Anatolia. His narratives are often repeated and cultivated in the Islamic press. When he desperately started seeking finance for his investment projects and was refused by rich financiers, the father of one of his former students came up with a sum and invested in the project. Mr. Bayram cites this incident as the starting point for Kombassan. As a missionary merchant he often travelled to Germany to give religious sermons in mosques, cafes and private homes and introduced his idea of bringing prosperity to Anatolia. The notions of 'teacher' and 'believer of Islam' were frequently used to convince potential investors through Islamic organisations with whom Kombassan had close ties. In a conservative city like Konya, where communities are tied to each other with respected figures like preachers and teachers, people usually know about leaders and educated people are admired; being a teacher and businessman brought recognition in the local and national media. Mr. Bayram as the CEO of Kombassan still prefers to be called 'the teacher'. A TV series titled 'The Chemistry Teacher' has even been produced by the company describing his poor childhood, intelligence, and the story of Kombassan.

${ }^{17}$ Another example is the chairman of Büyük Selçuklu Holding, a Kayseri-based company, who enjoyed the public visibility as the mayor of the city between 1994 and 1997 .
} 
of converts to the mission increased and further diffused into neighbourhoods and social network relations. The powerful narrative of Islamic missionary zeal perpetuates illusion, conviction and trust among those displaced masses who seek political power, spiritual and material wealth. Missionary merchants are key agents and opportunists for conveying the holy message through personal charisma and revelations. ${ }^{18}$ The sense of being unfairly marginalised but despite that using clever imagination is how Islamists portrayed themselves and their leaders. Açıkel (1999) gives a detailed account of the psychology behind this imaginary portrayal of ordinary, often poorly educated, Islamic leaders in Turkey. A similar reflection can be found in the Raiffeisenbank cooperative movement, which promoted Christian values, self-reliance, mutual self-help and motivation in the form of solidarity with Christian values in the late 19 th century. ${ }^{19}$

Rational reference to a third party usually helps to built trust. For example, $\mathrm{Y}$ may trust that $\mathrm{X}$, a young businessman who is also the son of a well-known businessman, will never breach a contract so as not to damage his father's reputation, or that his father will compensate unfulfilled commitments to protect his own reputation. Islam is a good reference to make risk calculations in this case. If $\mathrm{Y}$ is convinced that $\mathrm{X}$ is a true believer, he estimates that $\mathrm{X}$ is less likely to breach the contract since he believes that $\mathrm{X}$ will not risk his afterlife by breaching the contract. A preacher who played an intermediary role in money collecting activities states that in the meetings in Europe he swore that the owners of the companies are true believers and the returns they would obtain when they buy the 'shares' are approved by Islam. Many such preachers were involved in the process of collecting money from investors. ${ }^{20}$

In addition to small political organisations, representatives of the National Youth Foundation (Milli Gençlik Vakfı) in Germany and the Welfare Party were involved in Islamic activities and their promotion. These were the missionaries of the new Islamic revival who not only delivered sermons on Islam, ethics and morals but also heralded a new coming order under which moral supremacy, justice and fairness would reign.

\footnotetext{
${ }^{18}$ An interview in April 2001 with Mr. Haşim Bayram, Chairman of the Board of Kombassan remarkably illustrates this marriage of religion, entrepreneurship, charisma and opportunism.

${ }^{19}$ The still surviving cooperative movement is known by its founder's name, Friedrich Wilhelm Raiffeisen. See Matis (2002).

${ }^{20}$ In addition to anecdotal information in many newspaper articles, the study of the Turkey Research Centre in Essen provides valuable insight for this. See Special Report on Islamic Finance and Businesses, Turkey Research Centre, Essen, Germany, 1999.
} 


\section{Reproduction of trust through narratives of advertisements and investments}

Advertising is seen as a source of information about the prices and qualities of goods in the market. According to Nelson (1974), the volume of advertising is a signal to buyers that shows the extent of commitment invested by the seller. Concrete investments, like office buildings, factories, machinery, etc display better the company's apparent permanence in business. Advertisements are used by Islamic companies as an indicator of the permanence of the business. The title 'holding' is frequently used to impress potential investors as 'holding' is a term that refers to the umbrella company established in order to finance other sister companies in a group of firms.

A promotional video, a brochure and a website introducing company activities - with a degree of exaggeration depending on the intention of the entrepreneur - were the basics for starting an Islamic company. In these materials, nationalistic and religious motives were used intensely. In the advertisements, companies promised to establish factories in different fields, informed potential investors about their companies and investments in progress. Through these exaggerated advertisements, companies addressed the emotional, spiritual and nationalistic sentiments of potential investors. The success of Jet-Pa Holding measured in terms of the amount of money collected shows the influence of these advertisements. It is believed that JetPa collected around 200 million German marks from more than 20,000 investors. Jet-Pa was able to hide the fact that it had only a few small investments while another successful collector of assets, Endüstri Holding, was able to channel investments into lavish expenses for its managers with little economic activity. Jet-Pa with many ideas of high-tech investments ranging from aeroplane to automobile manufacturing was one of the top companies in advertisement expenditures. Jet-Pa also bought an undistinguished soccer team in the second league. They first switched the name of the team to Siirt Jet-Pa, made contracts with famous players and raised the team to the Premier League. Along with the success of the team, the popularity of soccer in Turkey contributed largely to the fame and recognition of Jet-Pa and its chairman Mr. Akgündüz. ${ }^{21}$

True entrepreneurs advertised massively as well but their reputations were subject to exploitation by swindlers like Jet-Pa. Investments by Yimpaş and Kombassan in Turkey and abroad pushed advertising to a secondary role. Kombassan bought Turkey's only jet-tyre plant from the state when it was

\footnotetext{
${ }^{21}$ The success of the Siirt Jet-Pa soccer team had a symbolic meaning for many people in Turkey. Siirt is a poor city in southeastern Turkey where Mr. Akgündüz promised to build an automobile factory.
} 
privatised, established an airline company operating between Turkey, Germany and the Netherlands, and established its holding headquarters in Konya. In addition to economic aspects, these investments had symbolic effects and are perceived by potential investors as indicators of business success and entrepreneurs' commitment to stay in business. When Kombassan built supermarkets in Germany they created concrete signals to lenders who were not able to monitor investment activities of the companies in Turkey. This aimed to provide an image of reliability in business and build trust. $^{22}$

\section{Repeated transactions}

Reputation gained through repeated transactions (Dasgupta, 2000; Diamond 1989) is the major source of trust observed in this system. Repeated exchange of trust among individuals and groups forged with rhetoric of Islamic economic revival expanded the scope of transactions to greater attractions through market reputation. Along with Islamist media and politics, communal ties and networks promoted Islamic holding companies. Advertisements were used and public gatherings were conducted in a diffused communal and personal manner. Especially in later stages, when the number of investors reached thousands and personal contacts between entrepreneurs and investors lost their importance, repeating transactions became crucial for new participation in the system. Internal commitment secured with the use of Islam and growing trust through repeated transactions attracted the growing number of investors while at the same time it raised the appetite for market opportunities for entrepreneur/managers as well as swindlers. Many investors imitated each other in investing and relied on one-sided, manipulated information about the companies.

The most common practice of investors was to 'invest and watch'. Participants invested small amounts in the beginning. If the company made payments regularly, they invested bigger amounts. ${ }^{23}$ Regular payments of dividends had external effects among both the investors and the companies. Some investors watched their relatives or friends who had invested in these companies before. Then, they invested their savings in the same company after they were convinced that the company was indeed paying back dividends. This is also true among companies. While regular payments

\footnotetext{
${ }^{22}$ Some infeasible and careless investments in the hands of incompetent managers went bankrupt as well.

${ }^{23}$ Companies offer other benefits as well. For instance, an investor who bought 25,000 DM in shares had the right to employ a relative or friend in one of Yimpaş companies. When the number of 25,000 DM investors caused over-employment in the company the holding raised the limit to 100,000 DM.
} 
strengthened the trust in the system, the opposite, failure of payments, had a devastating effect. The current crisis of trust mainly stemmed from the failure of several large holding companies with massive abuses.

\section{CONCLUSION: THE LIMITS OF TRUST IN MARKET EXCHANGE FOR DIRECT FINANCING}

In this study, we demonstrated that under certain circumstances direct financing can be more advantageous for some firms while others in the same market prefer to use financial institutions. Our paper argues that the rationale of Islamic companies and direct borrowing can be explained through basic economic principles. Islamic companies replaced financial institutions by reducing transaction costs based on the trust they built along with the shared morals of Islam. Trust between borrowers and lenders in this alternative form of finance is based on a calculative approach of the boundedly rational individuals and their communal ties. However, this regime was also subject to manipulations and abuse.

As argued by McClennen (2001), trust-based relations and transactions work best in the presence of bilateral interactions in which past-histories of individuals can be kept and the reputation of individual actions can be scrutinised. This is true for both investors who refrain from any speculation and managers who promise to manage the funds according to ethical and religious codes. However, as Islamic companies grew and the number of shareholders increased, bilateral interactions were replaced with multilateral and impersonalised interactions in which individuals were able to act with relative anonymity. ${ }^{24}$ In this expanded form, while there are reduced information costs and accumulative benefits of repeated transactions for the firm, the enforcement costs increase for investors. The anonymity brought by the increased number of investors and the increased size of companies finally works against the guarantees of the belief structure of internal morals, personal commitments and honesty. The temptations of cheating without being noticed or being accountable simply could not be tempered by the morals of Islam. Anonymity opens the door for misuse and paves the way for abuses by parties. Thus, the system, which is based on trust and mutual compliance among individuals within internalised religious moral values, collapses at this critical junction.

${ }^{24}$ In this discussion of anonymity versus impersonal trust there appears a question 'What is the optimal size of a community or business where trust can be maintained bilaterally and multilaterally?' We will deal with this issue elsewhere. 
Similarly, trust is subject to manipulations of opportunists and abusers. Gambetta's critical analysis of trust is both interesting and important for our analysis. As he states: 'Asking too little of trust is just as ill advised as asking too much... There is a wide range of anecdotal, historical, and sociological evidence to show that our capacity of self-delusion far exceeds rational optimistic expectations, and we can indeed make ourselves and others believe. Trust is of historical interest to us precisely in those cases where it is misplaced: it could not exist without betrayal, deception, and the disappointment our foolishness sustains' (Gambetta, 1988, pp. 232-233).

The collapse of several dishonest major Islamic holding companies and the management failures and abuses of the genuine ones causes a moral dilemma for believers. While the Islamic holding companies chose to personalise the trust among their investors, they assigned Islamic faith to maintain the needed impersonal trust for the financial regime and business survival. The managers of these companies persistently avoided dealing with the existing institutional and regulatory environment in legalising their multiownership structure and were thus subject to constant political and legal scrutiny primarily by the Capital Markets Board and the secular groups in Turkey. Shared belief in Islam was the main guarantee for the parties engaged in this company form but those who used Islam did not have a clear interpretation of the faith via-á-vis economics beyond increased enthusiasm for entrepreneurial activities. If Islamic groups and companies had remained the small, exclusive, and easily identifiable business groups as when they first began, they could have benefited from their isolated coherant nature in terms of imposing and enforcing trust-based relations.

But they instead chose to grow in very large numbers while both investors and managers failed to foresee the role of institutions in detecting and punishing abuses beyond the communal and personal fabric of Islamic groups. Thus, the lack of institutional and regulatory regimes whose engagement was not required for the initiation and survival of Islamic companies is making this moral collapse even more painful for the remaining investors, managers and local economies. The current readings of Islamic economics do not offer alternative institutions and regulatory frameworks to address the arising business problems either. ${ }^{25}$ This, nevertheless, does not

\footnotetext{
${ }^{25}$ See Kuran (1989), (1995), (1996) and (2001) for a detailed analysis of the rise of Islamic economics, its appeal for largely poor Muslim countries, and the flaws of Islamic economic principles. Apart from being highly consensus-oriented in solving economic problems, Islamic economics tends to reduce the recognition of individual liberty versus fairness and equality. As Kuran puts it: 'The positions taken by Islamic economists make clear, however, that in the event of conflict between an Islamic injunction and individual liberty, it is liberty that must yield' (1989, p. 187).
} 
mean that Islam is unfit for the free market but rather it shows that both thinkers and practitioners of Islam need to understand better how markets and institutions work in order to come up with a credible system with safeguards to improve economic development for Islamic societies.

The real question is whether there can be Islamic economic development beyond capitalism. The propaganda used by Islamists claim a better and just economic order for believers under Islamic order but the fundamentals of this order are not clearly defined and theorised. Islam's charitable provisions, commercial law and its emphasis on justice do not make it more or less favourable to capitalist development. As the current practice of Islamic regimes indicates, employment of Islamic principles themselves does not solve underdevelopment, poverty, or economic inequality. The experience of Turkish Islamic companies in direct financing further indicates that Islam's moral guard is also open to abuse in a loosely regulated and instituted capital markets regime. However, this experience also shows that Islamic societies seek new solutions within capitalist economic systems to maximise their gains and they do not wish to be destined to live in poverty and in backward societies. This is at least a hopeful recognition.

\section{REFERENCES}

Açıkel, F. 1996: Psychopathology of the holy synthesis. Toplum ve Bilim 70: 153-196.

Açıkel, F. 1999: Psychopathology of the holy synthesis: capitalism, nationalism and Islam in the foundation of Turkish-Islamic synthesis [Kutsal mazlumluğun psikopatalojisi]. Toplum ve Bilim 70: Autumn.

Akerlof, GA. 1970: The market for lemons: Qualitative uncertainty and the market mechanism. Quarterly Journal of Economics 84: 488-500.

Arrow, KJ. 1974: The limits of organization. W.W. Norton Company: USA.

Ben-Ner, A and Putterman, L. 1998: Values and institutions in economic analysis. In: Ben-Ner, A and Putterman, L (eds). Economics, Values, amd Organisation. Cambridge University Press: Cambridge.

Buğra, A. 1994: State and, business in modern Turkey. State University of New York Press.

Çakır, R. 1995: Ayet ve Slogan [Verse and Slogan]. Metis: Istanbul.

Coleman, J. 1990: Foundations of social theory. Harvard University Press: Cambridge, MA.

Çokgezen, M. 2000: New fragmentations and co-operations of the Turkish bourgeoisie. Government and Policy 18: 525-544.

Dasgupta, P. 2000: Trust as a commodity. In: Diego, G (ed). Trust: Making and Breaking Co-operative Relations. Basil Blackwell: Oxford.

Der Spiegel. 2004: Kriminalität: Wie türkishe Holdings Mulisme in Deutschland um Milliarden erelichterten [Crime: how Turkish Holdings acquired billions from Muslims in Germany], 26 January 2004, p. 36.

Diamond, D. 1984: Financial intermediation and delegated monitoring. Review of Economic Studies 51: 393-414.

Diamond, D. 1989: Reputation acquisition in debt markets. Journal of Political Economy 97: 828-862. 
Ensminger, J. 1997: Transaction costs and Islam: Explaining conversion in Africa. Journal of Institutional and Theoretical Economics 153: 4-29.

Eser, R. 1999: Hanehalki Tasarruf ve Yatirim Egilimleri Anketi Sonuclari [The survey results of the household saving and investment trend]. SPK yayinlari: Ankara.

Gambetta, D. 1988: Can we trust trust? In: Diego, G (ed). Trust: Making and Breaking Co-operative Relations. Basil Blackwell: Oxford.

Göle, N. 1999: Islam in Yeni Kamusal Yüzleri [New Public Faces of Islam], Istanbul: Metis.

Granovetter, M. 1985: Economic action and social structure: The problem of embeddedness. American Journal of Sociology 91: 481-510.

Greenwald, BC and Stiglitz, JE. 1990: Asymmetric information and the new theory of the firm: financial constraints and risk behaviour. The American Economic Review 80: 160-165.

Grief, A. 1994: Cultural beliefs and the organization of society: A historical and theoretical reflection on collectivist and individualistic societies. The Journal of Political Economy 102: 912-950.

Kuran, T. 1989: On the notion of economic justice in contemporary Islamic thought. International Journal of Middle East Studies 21: 171-191.

Kuran, T. 1995: Further reflections on the behavioural norms of Islamic economics. Journal of Economic Behavior and Organization 27: 159-163.

Kuran, T. 1996: The discontents of Islamic economic morality. American Economic Review 86: 438-442.

Kuran, T. 1997: The genesis of Islamic economics: A chapter in the politics of Muslim identity. Social Research 64: 301-338.

Kuran, T. 1998: Moral overloads and its alleviation. In: Ben-Ner, A and Putterman, L (eds). Economics, Values, amd Organisation. Cambridge University Press: Cambridge.

Kuran, T. 2003: The Islamic commmerical crisis: institutional roots of economic underdevelopment in the Middle East. Journal of Economic History 63: 414-446.

Lane, C and Bachman, R. 1996: The social constitution of trust: Supplier relations in Britain and Germany. Organization Studies 17: 365-395.

Leland, HE and Pyle, DH. 1977: Informational asymmetries, financial structure and financial intermediation. The Journal of Finance 32: 371-387.

Lyons, B and Mehta, S. 1997a: Private sector business contracts: The text between the lines. In: Deakin, S and Mickie, J (eds). Contracts, Cooperation and Competition. Oxford University Press: Oxford.

Lyons, B and Mehta, J. 1997b: Contracts, opportunism and trust: Self interest and social orientation. Cambridge Journal of Economics 21: 239-257.

Matis, H. 2002: Raiffeisen: A vision conquers the world. Raiffeisen Zentralbank Österreich AG (RZB): Vienna.

Maxfield, S and Schneider, BR. 1997: Business and the state in developing countries. Cornell University Press: Ithaca, NY.

McClennen, E. 2001: Trust and market exchange. Unpublished manuscript, Department of Philosophy, London School of Economics.

Mishkin, F. 1992: Anatomy of a financial crisis. Journal of Evolutionary Economics 2: 115-130.

Nelson, P. 1974: Advertising as Information. Journal of Political Economy 82: 729-754.

Noorderhaven, NG. 1996: Opportunism and trust in transaction cost economics. In: Groenewegen, J (ed). Transaction Cost Economics and Beyond. Kluwer Publishing: Dordrecht.

Odabaş1, H. 2001: Tabela holdingler son virajda [Fake holdings at last junction.] Aksiyon, 19.05.2001: 337 .

Özcan, GB. 1995: Small firms and local economic development; Entrepreneurship in southern Europe and Turkey. Avebury: Aldershot.

Özcan, GB and Çokgezen, M. 2003: Limits to alternative forms of capitalization: The case of Anatolian companies. World Development 31: 2061-2084. 
Özcan, YZ and Özcan, K. 2003: Measuring poverty and inequality in Turkey. Proceedings of Middle East and Economic Association.

Parry, J and Bloch, M. 1989: Money and morality of exchange. Cambridge University Press: Cambridge.

Pitelis, C. 1996: Seven reasons why 'beyond' transaction costs economics to Thesmoeconomics. In: Groenewegen, J (ed). Transaction Cost Economics and Beyond. Kluwer Publishing: Dordrecht.

Pressman, S. 1998: On financial frauds and their causes. The American Journal of Economics and Sociology 57: 405-421.

Sak, G. 1995: Public policies towards financial liberalization: A general framework and an evaluation of the Turkish experience in the 1980's. CBM Publication: Ankara.

Sako, M. 1998: Does trust improve business performance? In: Lane, C and Bachmann, R (eds). Trust Within and Between Organizations: Conceptual Issues and Empirical Applications. Oxford University Press: Oxford.

Shankland, D. 1999: Islam and Society in Turkey. London: Eothen Press.

Shayegan, D. 1992: Cultural schizophernia: Islamic societies confronting the west (Trans. John Howe). Saqi Books: London.

Special report on Islamic finance and businesses, Turkish Research Centre: Essen, Germany, 1999. Star. 2004: The Turkish daily (29.01.2004).

Tugal, C. 2002: Islamism in Turkey beyond instrument and meaning. Economy and Society 31: $85-111$.

White, J. 1994: Money makes us relatives. University of Texas: Austin.

Williamson, O. 1983: Credible commitments: Using hostages to support exchange. The American Economic Review 73(4): 519-540.

Williamson, O. 1987: The economic institutions of capitalism: Firms, markets, relational contracting. New York: Free Press.

Williamson, O. 1996: Calculativeness, trust, and economic organization. In: Williamson, O (ed). The Mechanisms of Governance. Oxford University Press: New York. 